\title{
Citizen science: an emerging professional field united in truth-seeking
}

Conference

Reviewed by

Abstract

Keywords
Citizen Science Association Conference

SaINT PaUL, Minnesota, U.S.A., 17-20th MaY 2017
The second biennial Citizen Science Association Conference was held from the 17-20th of May 2017 in Saint Paul, Minnesota. The conference is the biggest of its kind in the world and brought together more than 1,000 delegates for hundreds of conference presentations as well as workshops, panels, screenings, a hackathon and a citizen science festival. In this paper we review the history of the conference and outline the key events leading up to the 2017 conference.

Citizen science; Community action; Public engagement with science and technology

Citizen science is often described as "the engagement of non-professionals in scientific investigations" [Miller-Rushing, Primack and Bonney, 2012, p. 285]. Citizen science is also an emerging professional field with thousands of research projects engaging millions of participants around the world [Bonney et al., 2014]. As well as having an impact on science education and science governance, citizen science is considered to be one of the most dramatic developments in the field of science communication in recent years [Lewenstein, 2016].

There are now three major associations in the field of global citizen science - the Citizen Science Association, the European Citizen Science Association and the Australian Citizen Science Association. Storksdieck et al. [2016] provide a comprehensive description of how and why these association were established: "The associations have formed to support a shared understanding of the opportunities, evidence-based practices, successes, challenges, and emerging standards of expectation for excellence in citizen science, and to help those within and beyond the field realize opportunities to appreciate or effectively build on the momentum gathering around citizen science as an accepted approach for research, outreach, and informal and formal education" [p. 1]. The Citizen Science Association was launched in 2014 and, while it is based in the US, it boasts a global membership in excess of 4,000 individuals from more than 80 different countries. The association has both a journal ("Citizen Science: Theory and Practice") and a conference. The journal was first published in 2016 "to explore and better 
understand citizen science in all its facets - for example, lessons from successes and failures in the development and implementation of citizen science tools and projects; techniques for the communication and visualization of project results and measurement of outcomes; and critical examination of the many ways that citizen science can yield a range of scientific, educational, and social outcomes" [Bonney, Cooper and Ballard, 2016, p. 1]. The history of the conference, however, predates the formal launch of the association.

The initial ideas for hosting a citizen science conference can be traced back to the early 2000s, but it was the Public Participation in Scientific Research Conference, held in Portland, Oregon on the 4-5th of August 2012 that resulted in the forming of an organisation to support citizen science as a field [Miller-Rushing, 2013]. While that conference had 300 participants, by the time the inaugural Citizen Science Association Conference was taking place on the 11-12th of February 2015 in San Jose, California, there were more than 600 delegates. As the 2015 conference was part of a preconference of the Annual Meeting of the American Association for the Advancement of Science, the 2017 conference was the first independent citizen science conference of its kind. Its growth is not only due to the rapidly expanding field of citizen science itself, but also because of the role public engagement in science, science communication and citizen science is expected to play in the current politically unstable environment [Roche and Davis, 2017]. Important events in the month before the 2017 conference included a March for Science [Roche, 2017] and the month-long Citizen Science Day events [Hoffman, 2017]. Both of these occasions drew more attention to the 2017 Citizen Science Association Conference, particularly in light of the decision, in 2016, to change the venue of the conference.

The 2017 conference was originally scheduled to be held in Raleigh, North Carolina. Yet in March 2016 the state legislature in North Carolina passed a bill, which came to be known as "House Bill 2", that effectively removed nondiscrimination protections for transgender people in public restrooms and changing facilities. The board of directors of the Citizen Science Association, in consultation with the association's Integrity, Diversity and Equity Working Group and the Conference Programme Committee, and with input from members of the association, took the decision that it could not hold a conference in a place where a law was being introduced that was in opposition to the core values of safety, accessibility and equity for the association members [Newman, 2016]. As a consequence, the 2017 conference was moved to Saint Paul, Minnesota, and scheduled for the 17-20th of May.

The conference attracted more than 1,000 attendees and had hundreds of presentations, along with project slams, screenings, book panel discussions, workshops, a hackathon and a citizen science festival (see Figure 1). The opening reception was held in the Science Museum of Minnesota (see Figure 2), which provided free entrance to the museum for all delegates for the duration of the conference.

A running theme throughout the conference was the idea of "truth-seekers" being critical to science. This concept was first mentioned by Dr Marc Edwards in the opening keynote presentation of the conference and was revisited in many of the subsequent sessions. Dr Edwards is the Charles P. Lunsford Professor of Environmental and Water Resources Engineering at Virginia Tech and made 


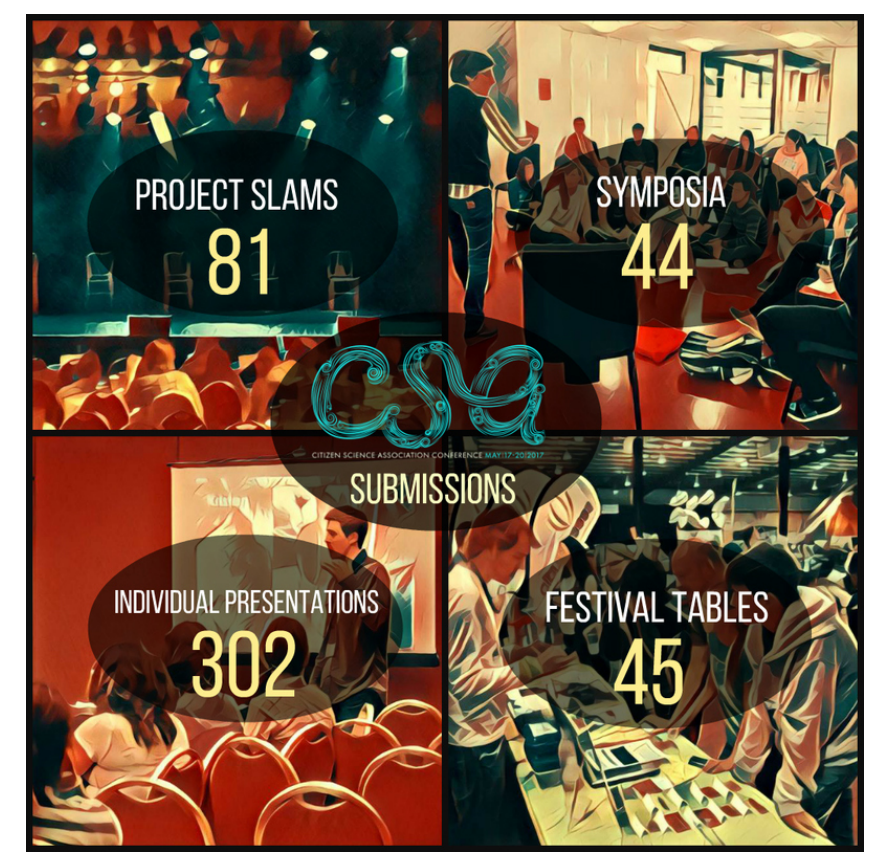

Figure 1. The conference showcased a variety of different types of presentations.

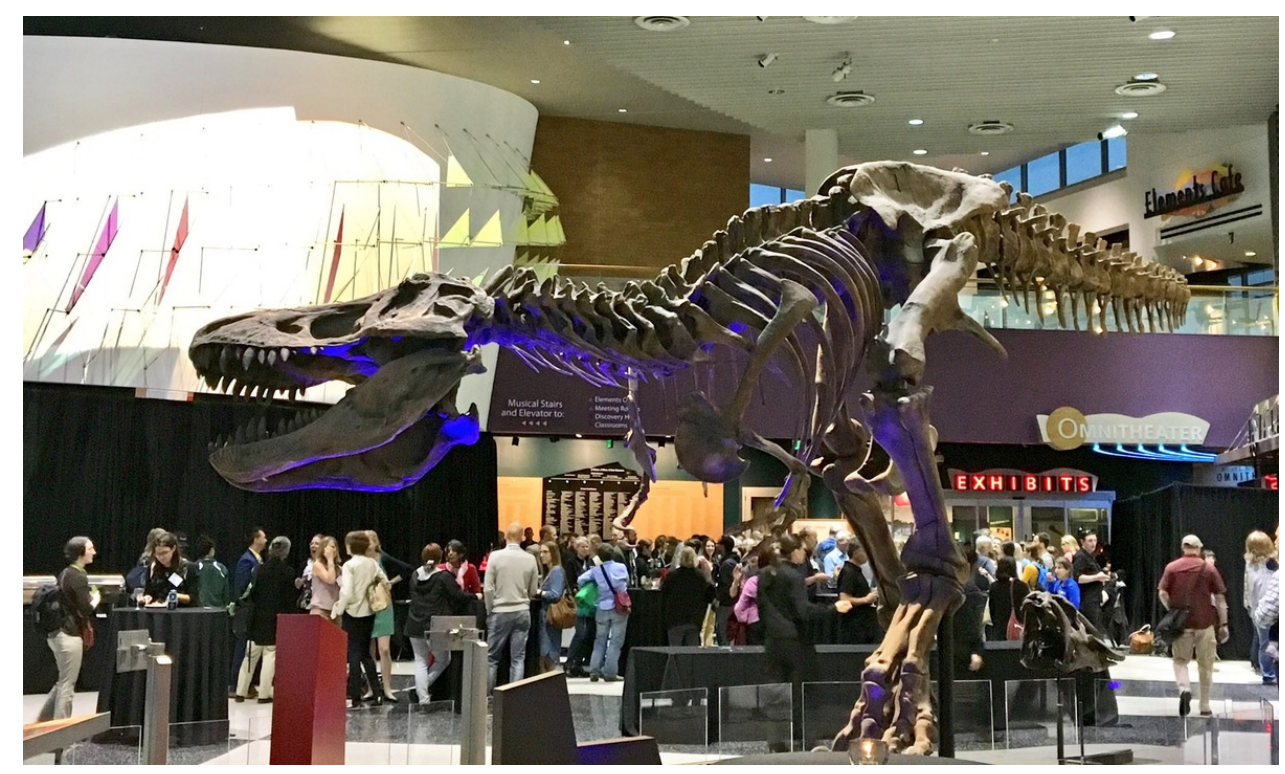

Figure 2. The opening reception in the Science Museum of Minnesota.

the point during his keynote address that when it comes to science - a person's commitment to discovering the truth is often more important than their academic qualifications. He was referring to Ms LeeAnne Walters, his co-presenter in the opening keynote, whom he described as being "an endangered species" because she is a "truth-seeker". Dr Edwards and Ms Walters were two of the key figures in bringing national and international attention to the Flint Water Crisis [HannaAttisha et al., 2016]. This crisis arose when the water supply in Flint, Michigan was dangerously contaminated and was only discovered through the determination of Ms Walters (a Flint resident who believed that her son had been poisoned by the Flint drinking water) and her collaboration with scientists such as Dr Edwards. 
The conference sessions targeted a range of different themes including: "Blurring Disciplines", "Grand Conversations", "Research Teams", "Measuring Outcomes", "Best Practices", "Empowering with Data", "Learning and Education", "Sharing Results" and "Impacting Policy". Over the course of the conference a number of challenges facing the field of citizen science emerged. A frequent topic of debate was the importance of using appropriate terminology. The choice of words used to describe participants, activities, and projects were seen to have a profound impact on the opinions and attitudes of those involved. As well as being discussed in several conference sessions, this issue was explored further in a paper published in the weeks after the conference by Eitzel et al. [2017] who describe how "much can be at stake depending on the choice of words used to describe citizen science, because terminology impacts how knowledge is developed" [p. 1].

Another issue that was stressed repeatedly in the conference was the need for a clear research agenda around citizen science and education. The perceived educational values of citizen science were discussed at length and reaffirmed all of the possible benefits that were highlighted by the Center for Advancement of Informal Science Education in 2009: "projects that directly involve members of the public in scientific research seem particularly suitable for increasing participants' understanding of science process, creating deep engagement in science, and developing multiple scientific skills including observation, study design, sampling, data collection, data analysis, and drawing conclusions from evidence" [Bonney et al., 2009, p. 47]. Several conference delegates mentioned how this agenda is now being tackled by a working group in a COST Action which has the objective: "to increase awareness about the possibilities of [citizen science] in education, by collating the knowledge of current practices and underscoring the meaning of [citizen science] in formal and informal education" [CS-EU, 2016, p. 10].

Many of the conference sessions focused on the successes of citizen science with a large number of the presentations highlighting individual citizen science projects. This is not surprising given that it was only the second formal Citizen Science Association Conference in a nascent professional field. Less discussion was given to the failures of individual citizen science projects or the potential damage that could be done by irresponsible citizen science. However, this point did feature in the opening keynote as Dr Edwards highlighted the dangers of "citizen science at its worst" when, during the water crisis in Flint, the Water Defense organisation (an environmental nonprofit organisation founded by the actor Mark Ruffalo) caused undue panic by spreading propaganda based on bad science and inaccurate data. Although probably well-meaning in its inception, this intervention in Flint showcased how citizen science can capitalise on public goodwill and, in the case of the Water Defense organisation, be exploited for personal profits as well as needlessly jeopardising the health of citizens.

In future conferences these dangers will have to be catalogued and explored to ensure that the rapidly expanding field of citizen science manages to keep sight of its own moral values. To this end, endeavours like the European Citizen Science Association's "Ten principles of citizen science" [ECSA, 2015] will become increasingly valuable. It is the intention of the conference organisers to hold the next Citizen Science Association Conference in Raleigh, North Carolina in March 2019. 
Acknowledgments The authors wish to acknowledge the support of the Irish Research Council through its "New Foundations" programme, Science Foundation Ireland through its "Discover" programme, the Trinity Long Room Hub Research Incentive Scheme and the Arts and Social Sciences Benefactions Fund at Trinity College Dublin. The authors also wish to thank the members of the Citizen Science Association who provided information and advice in the preparation of this review.

\section{References}

Bonney, R., Cooper, C. and Ballard, H. (2016). 'The Theory and Practice of Citizen Science: Launching a New Journal'. Citizen Science: Theory and Practice 1 (1). DOI: $10.5334 /$ cstp. 65.

Bonney, R., Ballard, H., Jordan, R., McCallie, E., Phillips, T., Shirk, J. and Wilderman, C. C. (2009). Public Participation in Scientific Research: Defining the Field and Assessing Its Potential for Informal Science Education. A CAISE Inquiry Group Report. Washington, DC, U.S.A.: Center for Advancement of Informal Science Education (CAISE). URL: http://www . informalscience.org/public-p articipation-scientific-research-defining-field-and-assessing-its-p otential-informal-science.

Bonney, R., Shirk, J. L., Phillips, T. B., Wiggins, A., Ballard, H. L., Miller-Rushing, A. J. and Parrish, J. K. (2014). 'Citizen science. Next steps for citizen science'. Science 343 (6178), pp. 1436-1437. DOI: $10.1126 /$ science.1251554. PMID: 24675940.

CS-EU (2016). Citizen Science COST Action - CA15212: to promote creativity, scientific literacy, and innovation throughout Europe. Memorandum of Understanding. pp.1-15. Brussels, Belgium: COST Association. URL: https://www.cs-eu.net/s ites/default/files/media/2017/04/CA15212-MoU.pdf.

ECSA (2015). 'Ten principles of citizen science'. European Citizen Science Association. URL: https://ecsa.citizen-science.net/sites/default/files/ecsa_ten_p rinciples_of_citizen_science.pdf.

Eitzel, M. V., Cappadonna, J. L., Santos-Lang, C., Duerr, R. E., Virapongse, A., West, S. E., Kyba, C. C. M., Bowser, A., Cooper, C. B., Sforzi, A., Metcalfe, A. N., Harris, E. S., Thiel, M., Haklay, M., Ponciano, L., Roche, J., Ceccaroni, L., Shilling, F. M., Dörler, D., Heigl, F., Kiessling, T., Davis, B. Y. and Jiang, Q. (2017). 'Citizen Science Terminology Matters: Exploring Key Terms'. Citizen Science: Theory and Practice 2 (1), pp. 1-20. DOI: 10.5334/cstp. 96.

Hanna-Attisha, M., LaChance, J., Sadler, R. C. and Schnepp, A. C. (2016). 'Elevated Blood Lead Levels in Children Associated With the Flint Drinking Water Crisis: A Spatial Analysis of Risk and Public Health Response'. American Journal of Public Health 106 (2), pp. 283-290. DOI: 10.2105/ajph.2015. 303003.

Hoffman, C. (2017). 'Announcing Citizen Science Day 2017!' Discover. URL: http://blogs .discovermagazine.com/citizen-science-salon/2017/01 /30/announcing-citizen-science-day-201.

Lewenstein, B. V. (2016). 'Can we understand citizen science?' JCOM 15 (1), E, pp. 1-5. URL: https://jcom.sissa.it/archive/15/01/JCOM_1501_2016_E.

Miller-Rushing, A. (2013). 'Workshop 1: Conference on Public Participation in Scientific Research 2012: An International, Interdisciplinary Conference'. Bulletin of the Ecological Society of America 94 (1), pp. 112-117. DOI: $10.1890 / 0012-9623-94.1 .112$.

Miller-Rushing, A., Primack, R. and Bonney, R. (2012). 'The history of public participation in ecological research'. Frontiers in Ecology and the Environment 10 (6), pp. 285-290. DOI: 10.1890/110278. 
Newman, G. (26th May 2016). 'In support of our core values: A conference decision'. Citizen Science Association. URL: http://citizenscience.org/2016/0 5/26/in-support-of-our-core-values-a-conference-decision.

Roche, J. (2017). 'People are taking to the streets to defend science - but it could come at a cost'. The Conversation.

URL: https://theconversation.com/people-are-taking-to-the-streets-to -defend-science-but-it-could-come-at-a-cost-76342.

Roche, J. and Davis, N. (2017). 'Should science communication play a role in political activism?' JCOM 16 (01), L01. URL: https://jcom.sissa.it/archive/16/01/JCOM_1601_2017_L01.

Storksdieck, M., Shirk, J. L., Cappadonna, J. L., Domroese, M., Göbel, C., Haklay, M., Miller-Rushing, A. J., Roetman, P., Sbrocchi, C. and Vohland, K. (2016). 'Associations for Citizen Science: Regional Knowledge, Global Collaboration'. Citizen Science: Theory and Practice 1 (2), pp. 1-10.

DOI: $10.5334 /$ cstp. 55.

Authors

Dr Joseph Roche is an Astrophysicist and Assistant Professor in Science Education at Trinity College Dublin. He teaches Science \& Society and Communicating Science on a Master in Science Education programme. His research area is the role of science in society. E-mail: Joseph.Roche@tcd.ie.

Nicola Davis is a Neuroscientist and has worked as a researcher in Trinity College Dublin, Goettingen University and Imperial College London. She has developed and coordinated national and European-funded public engagement events for the School of Education at Trinity College. E-mail: davisni@tcd.ie.

How to cite

Roche J. and Davis N. (2017). 'Citizen science: an emerging professional field united in truth-seeking'. JCOM 16 (04), R01. 